\title{
LETTER
}

\section{The prognostic value of concomitant assessment of NT-proCNP, C-reactive protein, procalcitonin and inflammatory cytokines in septic patients}

\author{
Ryszard Tomasiuk ${ }^{1}$, Malgorzata Mikaszewska-Sokolewicz ${ }^{2}$, Stanislaw Szlufik ${ }^{3 *}$, Piotr Rzepecki ${ }^{2}$ and Tomasz Lazowski ${ }^{2}$
}

\section{Findings}

The mortality of patients with sepsis in ICUs has been decreasing since 1991 [1]. Nevertheless, there are still conflicting data regarding potential biomarkers of mortality rate among critically ill patients and sepsis development. $\mathrm{N}$-terminal pro C-type natriuretic peptide (NT-proCNP) is one of the markers whose usefulness is still uncertain. Some authors have shown the possible role of NT-proCNP in the prognosis of critically patients with sepsis [2] and in polytrauma patients without brain injury who developed sepsis [3], but Gouel-Chéron and colleagues [4] showed no correlation between the serum level of NT-proCNP and development of sepsis.

Our study aimed to explore the serum level of NTproCNP and its potential triggers (TNF- $\alpha$, IL-6, IL-8, IL-10, IL-12) and to correlate them with serum levels of procalcitonin (PCT) and C-reactive protein (CRP) as reviewed by Uzzan and colleagues [5].

Samples were obtained from 90 critically ill adult patients during the first day in the ICU. The patients were divided in two groups: patients who died of sepsis in the ICU (43 patients), and ICU survivors (47 individuals). All patients were assessed with the use of Acute Physiology and Chronic Health Evaluation II score. ELISA kits were used for quantitative determination of human NT-proCNP. Cytokines were measured with the Fluorokine ${ }^{\circ}$ MAP cytokine multiplex kit and the Luminex 100 Platform. Statistical evaluation included Mann-Whitney U test and Spearman correlation coefficient.

The median serum level of NT-proCNP was significantly higher in non-survivors than in survivors: 7.1 (interquartile range (IQR) 3.7 to 18.1 ) $\mathrm{pmol} / \mathrm{L}$ versus 4.5 (IQR 2.3 to 7.2 ) pmol/L, $P<0.05$. Likewise, serum CRP levels were higher in non-survivors than in survivors:

\footnotetext{
* Correspondence: stanislaw.szlufik@gmail.com

${ }^{3}$ Department of Neurology, Faculty of Heath Science, Medical University of Warsaw, 02-091 Warsaw, Poland

Full list of author information is available at the end of the article
}

132.5 (IQR 77.6 to 180.8 ) $\mathrm{mg} / \mathrm{L}$ versus 93.8 (IQR 50.1 to $162.4) \mathrm{mg} / \mathrm{L}, P<0.05$. The differences in median PCT, IL-6, IL-8, IL-10, IL-12 and TNF- $\alpha$ levels did not reach statistical significance (Table 1).

Our study is in agreement with the studies by Koch and colleagues [2] and Bahrami and colleagues [3], supporting the possibly important role of NT-proCNP as a prognostic biomarker in sepsis. Inflammatory cytokines (like IL-1 and TNF- $\alpha$ ) are known to trigger the release of CNP from endothelial cells but, interestingly, this was not confirmed in our study (median levels of IL-1, TNF- $\alpha$, IL-6, and IL-10 were not statistically correlated with survival). In our study PCT was not a good prognostic factor either (possibly due to the small cohort of patients).

Determination of CRP and NT-proCNP can potentially determine the risk of death. Outcome prediction based on these biomarkers may have sound clinical implications. This requires further study in larger patient populations.

Table 1 Median serum levels of NT-proCNP, C-reactive protein, procalcitonin and inflammatory cytokines in non-survivors and survivors

\begin{tabular}{lcc}
\hline & \multicolumn{2}{c}{ Median (interquartiles) } \\
\cline { 2 - 3 } Parameter & Non-survivors & Survivors \\
\hline NT-proCNP* (pmol/L) & $7.1(3.7$ to 18.1$)$ & $4.5(2.3$ to 7.2$)$ \\
PCT $(\mathrm{ng} / \mathrm{ml})$ & $16.2(2.5$ to 36.2$)$ & $11.2(2.1$ to 38.4$)$ \\
CRP* $(\mathrm{mg} / \mathrm{L})$ & $132.5(77.6$ to 180.8$)$ & $93.8(50.1$ to 162.4$)$ \\
IL-6 $(\mathrm{pg} / \mathrm{mL})$ & $8.6(4.0$ to 47.6$)$ & $12.9(5.5$ to 57.5$)$ \\
IL-8 $(\mathrm{pg} / \mathrm{mL})$ & $167.7(34.9$ to 446.4$)$ & $175.2(50.2$ to 518.7$)$ \\
IL-10 $(\mathrm{pg} / \mathrm{mL})$ & $21.0(9.0$ to 57.0$)$ & $28.4(12.0$ to 66.0$)$ \\
IL-12 $(\mathrm{pg} / \mathrm{mL})$ & $3.5(2.4$ to 4.7$)$ & $3.1(2.0$ to 4.8$)$ \\
TNF-a $(\mathrm{pg} / \mathrm{mL})$ & $4.5(1.6$ to 6.2$)$ & $4.7(1.6$ to 6.0$)$ \\
\hline
\end{tabular}

${ }^{*} P<0.05$. CRP, C-reactive protein; IL, interleukin; NT-proCNP, N-terminal pro C-type natriuretic peptide; PCT, procalcitonin; TNF, tumor necrosis factor.

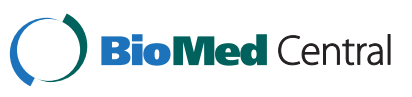

(c) 2014 Tomasiuk et al.; licensee BioMed Central Ltd. This is an Open Access article distributed under the terms of the Creative Commons Attribution License (http://creativecommons.org/licenses/by/2.0), which permits unrestricted use, distribution, and reproduction in any medium, provided the original work is properly credited. The Creative Commons Public Domain Dedication waiver (http://creativecommons.org/publicdomain/zero/1.0/) applies to the data made available in this article unless otherwise stated. 


\section{Abbreviations}

CRP: C-reactive protein; ELISA: Enzyme-linked immunosorbent assay;

IL: Interleukin; IQR: Interquartile range; NT-proCNP: N- terminal pro C-type natriuretic peptide; PCT: Procalcitonin; TNF: Tumor necrosis factor.

\section{Competing interests}

The authors declare that they have no competing interests.

\section{Author details}

'Department of Laboratory Diagnostics, Mazovian Brodno Hospital in Warsaw, 03-242 Warsaw, Poland. ${ }^{2}$ Department of Anesthesiology and Intensive Care, Medical University of Warsaw, 02-091 Warsaw, Poland. ${ }^{3}$ Department of Neurology, Faculty of Heath Science, Medical University of Warsaw, 02-091 Warsaw, Poland.

\section{Published: 25 Jun 2014}

\section{References}

1. Stevenson E, Rubenstein A, Radin G, Wiener R, Walkey A: Two decades of mortality trends among patients with severe sepsis: a comparative meta-analysis. Crit Care Med 2014, 42:625-631.

2. Koch A, Voigt S, Sanson E, Dückers H, Horn A, Zimmermann H, Trautwein C, Tacke F: Prognostic value of circulating amino-terminal pro-C-type natriuretic peptide in critically ill patients. Crit Care 2011, 15:R45.

3. Bahrami S, Pelinka L, Khadem A, Maitzen S, Hawa G, van Griensven M, Redl H: Circulating NT-proCNP predicts sepsis in multiple-traumatized patients without traumatic brain injury. Crit Care Med 2010, 38:161-166.

4. Gouel-Chéron A, Dupin M, Chanteperdix M, Chaillol I, Venet F, Pachot A, Monneret G, Floccard B, Allaouchiche B: Concomitant assessment of PSP and NT-proCNP as predictive markers of sepsis in severe trauma patients under mechanical ventilation. Crit Care 2013, 17:434.

5. Uzzan B, Cohen R, Nicolas P, Cucherat M, Perret G: Procalcitonin as a diagnostic test for sepsis in critically ill adults and after surgery or trauma: a systematic review and meta-analysis. Crit Care Med 2006, 34:1996-2003.

$10.1186 / \operatorname{cc} 13944$

Cite this article as: Tomasiuk et al.: The prognostic value of concomitant assessment of NT-proCNP, C-reactive protein, procalcitonin and inflammatory cytokines in septic patients. Critical Care 2014, 18:440 